\title{
A NEW SPECIES OF SPRINGSNAIL (PYRGULOPSIS) FROM THE OWYHEE RIVER BASIN, NEVADA
}

\author{
Robert Hershler ${ }^{1,2}$ and Hsiu-Ping Liu ${ }^{3}$
}

\begin{abstract}
We describe a new springsnail species, Pyrgulopsis cybele, from the Owyhee River basin (northwestern Nevada) based on morphologic and molecular (mtCOI) evidence. Pyrgulopsis cybele differs from other members of its genus in its unique pattern of penial ornament, which consists of small glands on the distal edge of the penial lobe, base of the penial filament, and outer edge of the medial section of the penis. It is further differentiated from regional congeners by its thickened inner-shell lip and mtCOI sequences. A Bayesian analysis based on COI data placed P. cybele in a well-supported clade that contained congeners from Snake River, Great Basin, Colorado River, and California Pacific Coastal drainages; the sister taxon of this new species was not resolved. The COI divergence of $P$. cybele relative to its most genetically similar congener $(P$. glandulosa) suggests that it evolved subsequent to emplacement of the Miocene basalt that carpets the upper South Fork Owyhee basin. Pyrgulopsis cybele was collected from 2 closely proximal springs along the South Fork Owyhee River below the Nevada Pipeline Crossing. Although these populations are in a remote wilderness study area, they may be threatened by livestock grazing and human disturbance.
\end{abstract}

Resumen.-Describimos una nueva especie de caracol de manantial, Pyrgulopsis cybele, de la cuenca del Río Owyhee (al noroeste de Nevada), con base en evidencias morfológicas y moleculares (mtCOI). Pyrgulopsis cybele difiere de otros miembros de su género debido a su ornamentación única en el pene, la cual consiste de pequeñas glándulas en el extremo distal del lóbulo, en la base del filamento y en el extremo exterior de la sección media del pene. Se distingue aún más de sus congéneres regionales debido a que el labio interno de la concha está engrosado y a las secuencias del gen mtCOI. Un análisis Bayesiano basado en datos del COI (citocromo $c$ oxidasa subunidad I) colocó a P. cybele en un clado bien apoyado que incluyó a congéneres del Río Snake, de la Gran Cuenca, del Río Colorado y de algunos ríos de la costa del Pacífico en California; no se resolvió el taxón hermano de esta nueva especie. La divergencia en el COI de $P$. cybele con respecto a su congénere genéticamente más similar (P. glandulosa) sugiere que evolucionó posteriormente al asentamiento de basalto del Mioceno que cubre la parte alta de la cuenca South Fork Owyhee. Se colectó P. cybele de dos manantiales cercanos entre sí a lo largo del Río South Fork Owyhee y por debajo del cruce del gaseoducto de Nevada (Nevada Pipeline Crossing). A pesar de que estas poblaciones se encuentran en un área de estudio silvestre y remota, podrían estar siendo amenazadas por la ganadería y por perturbaciones humanas.

Pyrgulopsis is a western North American genus of hydrobiid gastropods that is distributed from the Snake-Columbia River basin and Missouri River headwaters to the lower Rio Grande basin (Hershler et al. 2008: fig. 1). The tiny, gillbreathing species in this genus typically live in springs and have very small geographic ranges (Hershler and Sada 2002). Pyrgulopsis contains 133 species (Hershler and Liu 2010, Hershler et al. 2010), more than half of which (78 of 133, $58 \%$ ) have been described since 1995 . The actual number of species in this genus is probably considerably larger than currently recognized, given that many putative novelties have not been formally treated taxonomically (e.g., Frest and Johannes 1995, Liu et al. 2003) and given that much of the West still has not been surveyed well for these tiny animals.
Four Pyrgulopsis species have been previously reported from the Owyhee River watershed, a remote and rugged subunit of the Snake River basin that occupies ca. $10,950 \mathrm{mi}^{2}(28,360$ $\mathrm{km}^{2}$; Hardy et al. 2004) in Idaho, Nevada, and Oregon (Hershler 1998, Hershler and Liu 2009). Three of these species (Pyrgulopsis fresti, Pyrgulopsis intermedia, and Pyrgulopsis owyheensis) are distributed within a reach that extends from slightly above Three Forks to slightly above Owyhee Reservoir, Oregon; the fourth (Pyrgulopsis sadai) is found in the East Little Owyhee River drainage, Nevada (Fig. 1). In 2009 the first author discovered a population of Pyrgulopsis along the South Fork of the Owyhee River near the Oregon-Nevada border $>100 \mathrm{~km}$ upflow from Three Forks (Fig. 1). A second, closely proximal population was discovered in

\footnotetext{
${ }^{1}$ Department of Invertebrate Zoology, Smithsonian Institution, Box 37012, Washington, DC 20013-7012

2E-mail: hershlerr@si.edu
}

${ }^{3}$ Department of Biology, Metropolitan State College of Denver, Denver, CO 80217. 


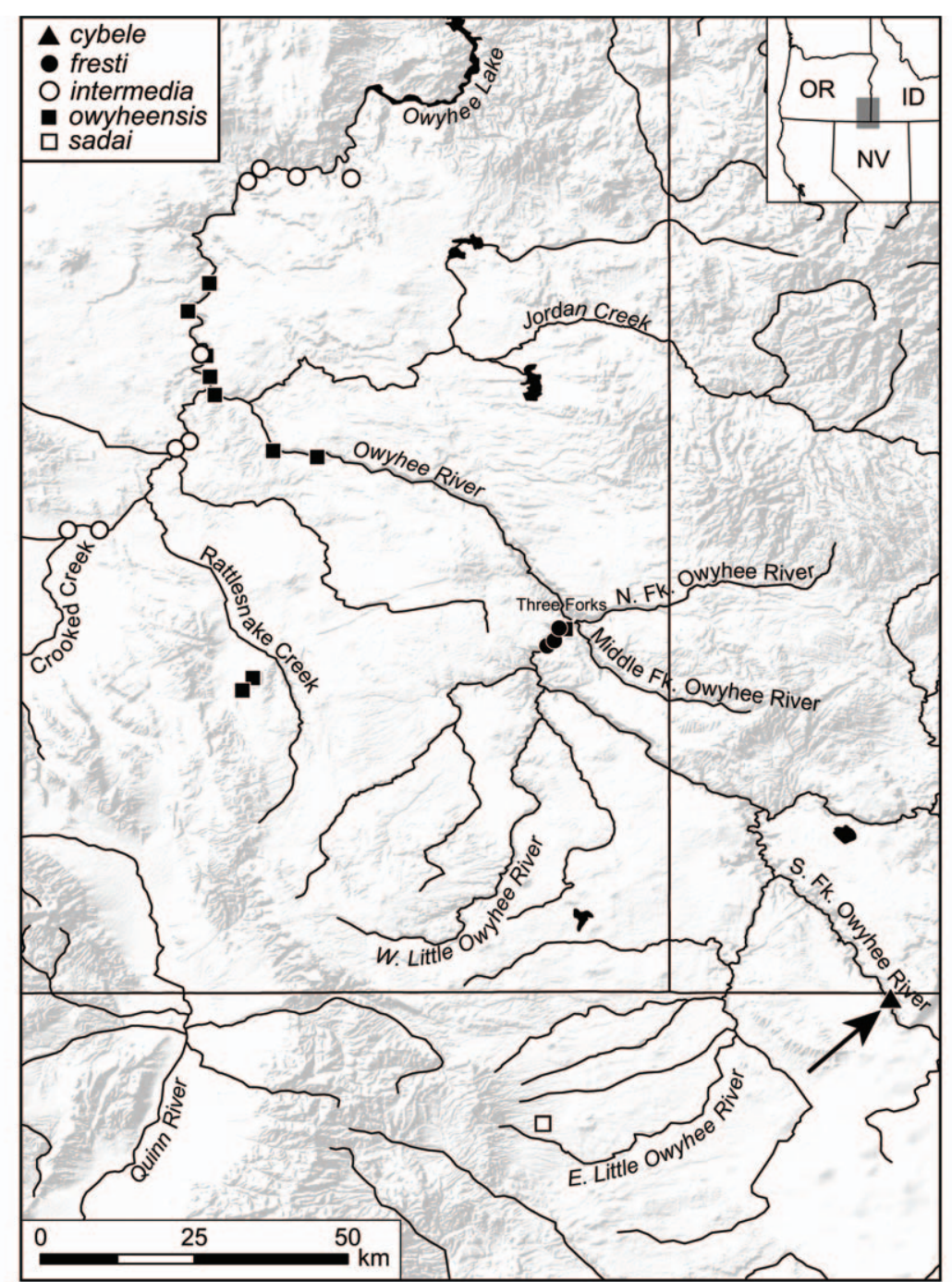

Fig. 1. Map showing the distribution of Pyrgulopsis species in the Owyhee River basin. The arrow points to the area inhabited by Pyrgulopsis cybele.

2010. Here we describe these populations as a new species of Pyrgulopsis based on morphological and molecular evidence. We also evaluate the phylogenetic relationships of this species and discuss its conservation status.

\section{METHODS}

Specimens were relaxed with menthol crystals and fixed in dilute formalin for anatomical study. Snails used for mtDNA sequencing were preserved in $90 \%$ ethanol in the field. Coordinates for the collecting localities were obtained in the field using a Garmin Oregon 450t GPS unit (UTM NAD 83). Types for the new species and other voucher material from this study were deposited in the Smithsonian Institution's National Museum of Natural History (USNM) collection.

Five females and 5 males (all adults) from the type locality of the new species were dissected; large series of males from both localities were examined to assess variation in penial glandular ornament. Variation in the number of cusps on the radular teeth was assessed using the method of Hershler et al. (2007). Other methods of morphological study and descriptive terminology are those used in recent taxonomic 
investigations of Pyrgulopsis (Hershler 1998, Hershler et al. 2003a). Basic statistics were compiled for the shell data using Systat for Windows 11.00.01 (SSI 2004).

Genomic DNA was extracted from entire snails using a CTAB protocol (Bucklin 1992). A $658 \mathrm{bp}$ segment of cytochrome $c$ oxidase subunit I (COI) corresponding to "Folmer's fragment" (Folmer et al. 1994) was amplified and sequenced with primers LCO1490 and HCOI2198 following protocols of Liu et al. (2003). Sequences were determined for both strands and then edited and aligned using Sequencherä version 4.8. We sequenced 3-6 specimens from the 2 samples of the new species described herein to assess variation. Sample information and GenBank accession numbers for the sequenced specimens utilized in this study are in Table 1. The new sequences reported herein were deposited in GenBank under accession numbers JN255350-JN255358 (Table 1).

Sequence divergences (uncorrected p distances) were calculated using MEGA5.05 (Tamura et al. 2011). Preliminary molecular phylogenetic analyses, which included most of the currently recognized species of Pyrgulopsis, consistently positioned the novelty described herein in a clade with 9 other congeners. The final analysis included all of these taxa and 2 congeners that belong to a different clade from the northern Lahontan basin; one of these congeners (Pyrgulopsis gibba) was used as the root. Phylogenetic relationships were inferred using Bayesian inference in MrBayes 3.12 (Ronquist and Huelsenbeck 2003). MrModeltest (Nylander 2004) selected the general time reversible model (GTR + G), which best fit the data under the Akaike information criterion. In the initial Bayesian analysis, the burn-in was set at $10 \%$ (10,000 generations) of the chain length $(100,000$ generations). Three runs were conducted in MrBayes using the General Time Reversible model (GTR + G) selected by MrModeltest and the default random tree option to determine when the log-likelihood sum reached a stable value (by plotting the log-likelihood scores of sample points against generation time). The ln likelihoods started around -7550 and quickly converged upon a stable value of about -1700 after 8000 generations. For the final run, Metropolis-coupled Markov chain Monte Carlo simulations were performed with 4 chains for 1,000,000 generations, and Markov chains were sampled at intervals of 10 generations to obtain
100,000 sample points. The sampled trees with branch lengths were used to generate a $50 \%$ majority-rule consensus tree with the first 5000 trees (equal to 50,000 generations) removed to ensure that the chain sampled a stationary portion.

\section{SystematiC Description}

Family Hydrobiidae Troschel, 1857

Subfamily Nymphophilinae Taylor, 1966

Genus Pyrgulopsis Call and Pilsbry, 1886

Type species: Pyrgula nevadensis Stearns, 1883, by original designation.

Diagnosis: Liu and Hershler (2005:296).

Pyrgulopsis cybele, new species

Trpes.-Holotype, USNM 1148155, unnamed spring brook on east side of South Fork Owyhee River, Elko County, Nevada, N 4648124, E 524954, Zone 11, 1439 m elevation, coll. RH and Chris Hansen, 1 November 2010. Paratypes (from same lot), USNM 1157696 (ca. 400 specimens).

ETYMoLOGY.-This species is named after Cybele, the Roman goddess of nature.

Referred material: NEVADA. Elko County: USNM 1128557 (ca. 150 specimens), unnamed spring brook on east side of South Fork Owyhee River, ca. $100 \mathrm{~m}$ north of the above, N 4645315, E 525593, Zone 11, 1463 m elevation, coll. RH, 2 June 2009.

DiagnOSIS.-A small species of Pyrgulopsis having a trochoid to ovate-conic shell with highly convex whorls and a thickened inner apertural lip. Penis having a medium-sized lobe and medium-length filament; ornament consisting of penial gland, Dg1, and terminal gland.

DESCRIPTION.-Shell trochoid to ovate-conic (Fig. 2A-D); height 1.6-2.8 mm; whorls 3.254.00. Periostracum tan. Protoconch near planispiral, about 1.4 whorls, diameter about $420 \mu \mathrm{m}$, initial portion weakly wrinkled (Fig. 2E, 2F). Teleoconch whorls highly convex, shouldered, sutures impressed, last whorl sometimes slightly loosened behind aperture; smooth apart from collabral growth lines. Aperture large, ovate, angled above. Inner lip complete, usually slightly disjunct, rarely adnate, thickened internally, sometimes markedly so; columellar shelf usually absent, narrow to moderate width when present; outer lip usually thin, sometimes thickened adapically, prosocline. Umbilicus usually small, narrow, rarely absent. Shell measurements and 
TABLE 1. Specimen codes, localities, and GenBank accession numbers for Pyrgulopsis species that were included in the molecular phylogenetic analysis.

\begin{tabular}{|c|c|c|c|}
\hline Species & Specimen code & Locality & Accession number \\
\hline \multirow[t]{2}{*}{ cybele } & P237A-F & $\begin{array}{l}\text { Spring brook entering north side of South Fork } \\
\text { Owyhee River, Elko Co., NV }\end{array}$ & JN255353-JN255358 \\
\hline & P252A-C & $\begin{array}{l}\text { Spring brook entering north side of South Fork } \\
\text { Owyhee River, Elko Co., NV }\end{array}$ & JN255350-JN255352 \\
\hline gibba & P134B, D & $\begin{array}{l}\text { Springs west of Fee Reservoir, Surprise Valley, } \\
\text { Lassen Co., CA }\end{array}$ & AY197603a, AY426359b \\
\hline glandulosa & & $\begin{array}{l}\text { Nelson Place spring, Verde River basin, } \\
\text { Yavapai Co., AZ }\end{array}$ & AY627959a \\
\hline imperialis & $\mathrm{P} 140 \mathrm{~A}, \mathrm{C}$ & $\begin{array}{l}\text { Spring, Thacker Pass, Kings River Valley, } \\
\text { Humboldt Co., NV }\end{array}$ & AY379450c, AY426350 b \\
\hline \multirow[t]{9}{*}{ intermedia } & P1B, E & $\begin{array}{l}\text { Crooked Creek, Highway } 95 \text { crossing, Owyhee } \\
\text { River basin, Malheur Co., OR }\end{array}$ & AY379442c, AY426351b \\
\hline & $\mathrm{P} 2 \mathrm{~B}, \mathrm{C}$ & $\begin{array}{l}\text { Crooked Creek at Crooked Creek State Wayside } \\
\text { (19/v/2000), Owyhee River basin, Malheur } \\
\text { Co., OR }\end{array}$ & $\mathrm{AY} 426352^{\mathrm{b}}, \mathrm{AY} 426353^{\mathrm{b}}$ \\
\hline & $\mathrm{P} 4 \mathrm{~B}, \mathrm{C}$ & Skylight Spring, Barren Valley, Malheur Co., OR & AY379444", AY379445c \\
\hline & IP60A-D & $\begin{array}{l}\text { Crooked Creek at Crooked Creek State Wayside } \\
\text { (16/vii/2006), Owyhee River basin, Malheur } \\
\text { Co., OR }\end{array}$ & $\begin{array}{l}\text { FJ172460d, FJ172461d, } \\
\text { FJ172462d, FJ172463 }\end{array}$ \\
\hline & IP67A, C & $\begin{array}{l}\text { Spring tributary to Birch Creek, Owyhee River } \\
\text { basin, Malheur Co., OR }\end{array}$ & FJ172468d, FJ172469d \\
\hline & P217A & $\begin{array}{l}\text { Spring along Owyhee River, above Long Sweet- } \\
\text { water Rapids, Owyhee River basin, Malheur } \\
\text { Co., OR }\end{array}$ & FJ172488d \\
\hline & $\mathrm{P} 222 \mathrm{~A}, \mathrm{C}$ & $\begin{array}{l}\text { Spring on hillside, Jackson Hole, Owyhee River } \\
\text { basin, Malheur Co., OR }\end{array}$ & $\mathrm{FJ} 172496^{\mathrm{d}}, \mathrm{FJ} 172497^{\mathrm{d}}$ \\
\hline & $\mathrm{P} 223 \mathrm{~A}, \mathrm{~B}$ & $\begin{array}{l}\text { Mouth of Rinehart Creek, Owyhee River basin, } \\
\text { Malheur Co., OR }\end{array}$ & FJ172498d, FJ172499d \\
\hline & $\mathrm{P} 224 \mathrm{C}$ & $\begin{array}{l}\text { Spring west of Two Mile Spring, Owyhee River } \\
\text { basin, Malheur Co., OR }\end{array}$ & FJ172500d \\
\hline militaris & P147A, C & $\begin{array}{l}\text { Spring west of Soldier Meadow Ranch, Black } \\
\text { Rock Desert, Humboldt Co., NV }\end{array}$ & AY197596a, AY426362b \\
\hline montezumensis & & $\begin{array}{l}\text { Montezuma Well, Verde River basin, Yavapai } \\
\text { Co., AZ }\end{array}$ & AY485552e \\
\hline \multirow[t]{2}{*}{ morrisoni } & Pmor5 & Page Springs, Verde River basin, Yavapai Co., AZ & AY485551 \\
\hline & P150A & $\begin{array}{l}\text { Spring, Bubbling Pond Hatchery, Verde River } \\
\text { basin, Yavapai Co., AZ }\end{array}$ & DQ364007f \\
\hline \multirow[t]{4}{*}{ robusta } & D33C, D & XL Spring, Abert Lake basin, Lake Co., OR & AY426348b, AY426349b \\
\hline & P3B, D & Hughet Spring, Harney basin, Harney Co., OR & AY379430c, AY379431 c \\
\hline & $\mathrm{P} 5 \mathrm{~B}, \mathrm{C}$ & $\begin{array}{l}\text { South Fork Malheur Reservoir, Malheur Cave } \\
\text { Road crossing, Malheur River basin, } \\
\text { Harney Co., OR }\end{array}$ & AY379432c, AY379433c \\
\hline & $\mathrm{P} 179 \mathrm{~A}, \mathrm{~B}$ & $\begin{array}{l}\text { Snake River, Glenns Ferry, Snake River basin, } \\
\text { Elmore Co., ID }\end{array}$ & AY379426c, AY379427c \\
\hline simplex & & $\begin{array}{l}\text { Spring near Strawberry, Verde River basin, } \\
\text { Yavapai Co., AZ }\end{array}$ & AY627949g \\
\hline sola & & $\begin{array}{l}\text { Brown Springs, Verde River basin, Yavapai } \\
\text { Co., AZ }\end{array}$ & AY627957g \\
\hline stearnsiana & & $\begin{array}{r}\text { Stream in Little Sycamore Canyon, southern } \\
\text { California coastal drainage, Ventura Co., CA }\end{array}$ & GQ275094h \\
\hline
\end{tabular}

aHershler et al. 2003b

bHershler and Liu 2004b

Hershler and Lic 2004

cHershler and Lin 2004a

dHershler and Liu 2009

eHurt 2004

fHershler and Liu 2008

gLiu and Hershler 2005

hHershler and Liu 2010 


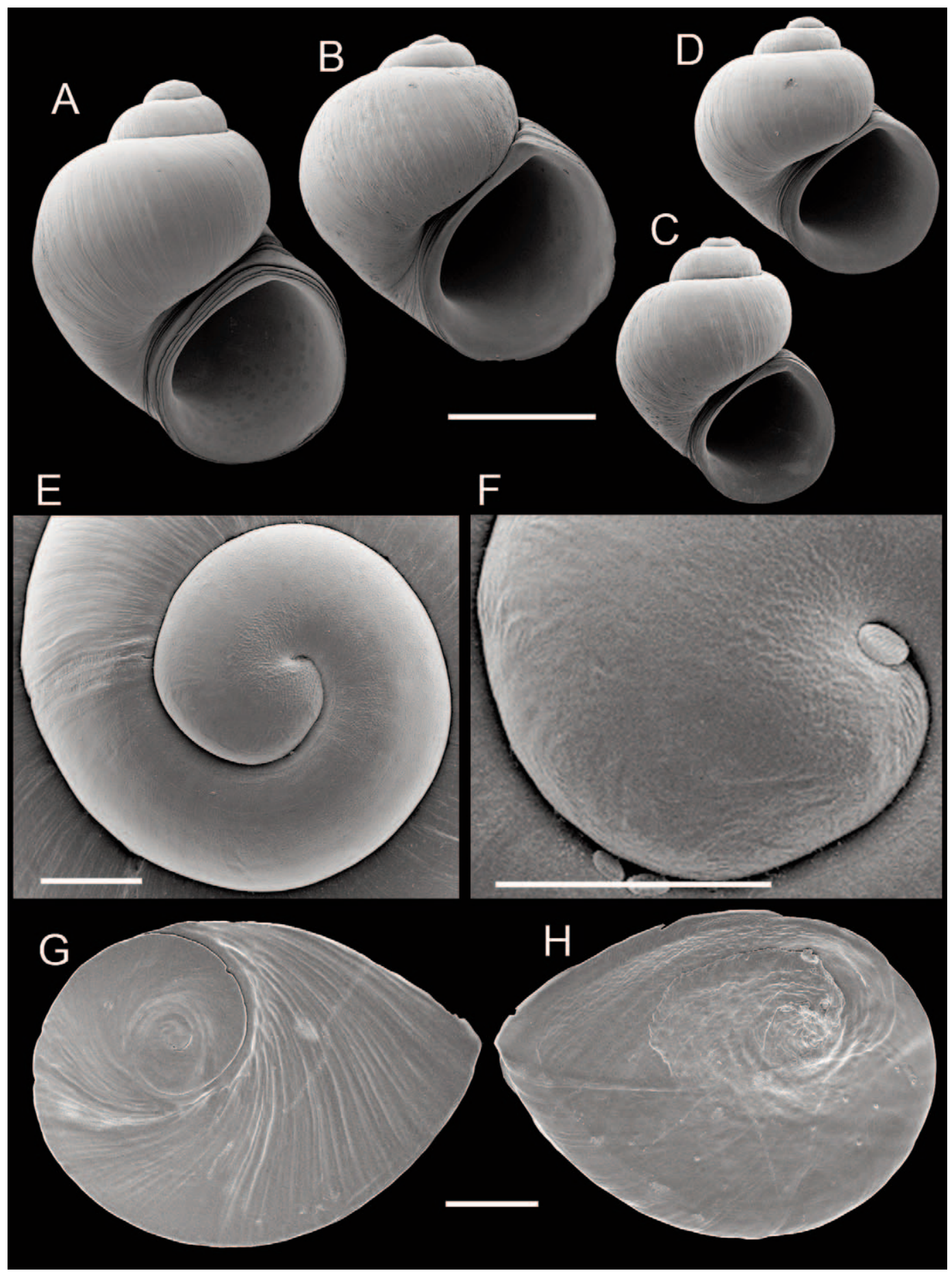

Fig. 2. Scanning electron micrographs of shells and opercula of Pyrgulopsis cybele: A, holotype, USNM 1148155; B, shell, USNM 1157696; C and D, shells, USNM 1128557; E, shell apex, USNM 1157696; F, close-up showing protoconch sculpture, USNM 1157696; G, operculum, outer side, USNM 1157696; H, operculum, inner side, USNM 1157696. Scale bars: A-D = $1.0 \mathrm{~mm} ; \mathrm{E}, \mathrm{F}=100 \mu \mathrm{m}$; G, $\mathrm{H}=200 \mu \mathrm{m}$. 
TABLE 2. Shell measurements (mm), whorl counts, and shell ratios for Pyrgulopsis cybele. WH = total number of shell whorls, $\mathrm{SH}=$ shell height, $\mathrm{SW}=$ shell width, $\mathrm{HBW}=$ body whorl height, $\mathrm{WBW}=$ body whorl width, $\mathrm{AH}=$ aperture height, $\mathrm{AW}=$ aperture width.

\begin{tabular}{|c|c|c|c|c|c|c|c|c|c|c|}
\hline & WH & $\mathrm{SH}$ & SW & HBW & WBW & $\mathrm{AH}$ & AW & $\mathrm{SW} / \mathrm{SH}$ & $\mathrm{HBW} / \mathrm{SH}$ & $\mathrm{AH} / \mathrm{SH}$ \\
\hline \multicolumn{11}{|c|}{ HOLOTYPE, USNM 1148155} \\
\hline & 4.00 & 2.81 & 2.14 & 2.42 & 1.74 & 1.50 & 1.36 & 0.76 & 0.86 & 0.53 \\
\hline \multicolumn{11}{|c|}{ PARATYPES, USNM $1157696(n=20)$} \\
\hline Mean & 3.83 & 2.42 & 1.92 & 2.11 & 1.53 & 1.33 & 1.19 & 0.79 & 0.87 & 0.55 \\
\hline SD & 0.14 & 0.18 & 0.13 & 0.15 & 0.08 & 0.10 & 0.09 & 0.05 & 0.01 & 0.03 \\
\hline Minimum & 3.50 & 2.11 & 1.74 & 1.87 & 1.40 & 1.21 & 1.06 & 0.70 & 0.84 & 0.49 \\
\hline Maximum & 4.00 & 2.74 & 2.26 & 2.42 & 1.67 & 1.59 & 1.38 & 0.86 & 0.90 & 0.59 \\
\hline
\end{tabular}

whorl counts for the holotype and paratypes are given in Table 2.

Operculum thin, amber, nuclear region and inner edge darker, multispiral with eccentric nucleus; last 0.5 whorl frilled on outer side (Fig. 2G); attachment scar border variably thickened (Fig. 2H). Radula (Fig. 3A) with about 58 well-formed rows of teeth. Central teeth about $20 \mu \mathrm{m}$ wide, cutting edge highly concave (Fig. 3B); lateral cusps 5-7; central cusp rounded or weakly pointed, pointed, parallel-sided proximally; basal cusp 1, small; basal tongue rounded, about as long as lateral margins. Lateral tooth face rectangular, angled; central cusp pointed (Fig. 3C), sometimes bifurcate; lateral cusps 2-3 (inner), 3-5 (outer); outer wing medium width, variably flexed, about $200 \%$ length of cutting edge; basal tongue variably developed. Inner marginal teeth having 18-24 cusps (Fig. 3D). Outer marginal teeth having 20-31 cusps; inner edge with rectangular wing (Fig. 3E). Radular count data were from USNM 1157696.

Animal rather darkly pigmented (brown or black). Cephalic tentacles pale distally. Distal lips of snout pale. Ctenidium positioned a little in front of pericardium; ctenidial filaments 13-18 $(n=5)$, rather large, triangular, apices on right, lateral surfaces weakly ridged. Pallial section of kidney rather large. Osphradium narrow, positioned slightly posterior to middle of ctenidium. Hypobranchial gland absent. Prostate gland bean-shaped, ovate and thin walled in section, with about $33 \%$ of length in pallial roof. Anterior vas deferens opening from ventral edge of prostate gland a little in front of pallial wall, section of duct on columellar muscle having a pronounced bend. Penis medium-sized, base square or rectangular, folded along inner edge proximally; filament medium length, narrow, tapering, slightly oblique; lobe medium-sized, rectangular, slightly oblique (Fig. 4A, 4B).
Penis usually bearing a narrow gland (Dgl) along outer edge near mid-length and small penial gland positioned along outer edge of filament basally (28 of 30 specimens examined); one specimen differed in lacking a penial gland, and one specimen differed in having a single gland on outer edge extending from mid-length onto the filament and a glandular spot on the ventral surface of the lobe (Fig. 4B, 4C). Penial duct nearly straight, very narrow, near outer edge. Penial filament pigmented with black granules along proximal $66 \%$ of length, pigment granules also scattered on dorsal surface of penis proximally. Female glandular oviduct and associated structures shown in Fig. 4D-4F. Coiled oviduct posterior-oblique, proximal arm kinked. Bursa copulatrix small, ovate, horizontal, largely overlapped by albumen gland. Bursal duct short, narrow, opening from distal edge, sometimes partly embedded in albumen gland, junction with common duct a little in front of posterior wall of pallial cavity. Seminal receptacle small, sac-like, overlapping anterior portion of bursa copulatrix. Albumen gland almost entirely visceral. Capsule gland shorter than albumen gland, composed of 2 distinct tissue sections. Genital aperture a terminal slit.

DisTRIBUTION AND HABITAT.-Pyrgulopsis cybele was collected from 2 small, closely proximal spring brooks (ca. $100 \mathrm{~m}$ apart) that discharge into a section of the South Fork Owyhee River known as the Devil's Pinball (BLM 2011; Fig. 5). Neither of these springs is shown on the USGS 7.5-minute topographic map of this area (Rubber Hill, Nevada-Idaho Quadrangle, 1973). This area is ca. $5.25 \mathrm{~km}$ downflow from the Nevada Pipeline river crossing and ca. 50 $\mathrm{km}$ (airline) west-southwest of Owyhee, Nevada. Snails were moderately abundant on stones and cobble in the lower reaches of these spring brooks, which flow down steep talus slopes on the east side of the river. This species was not 


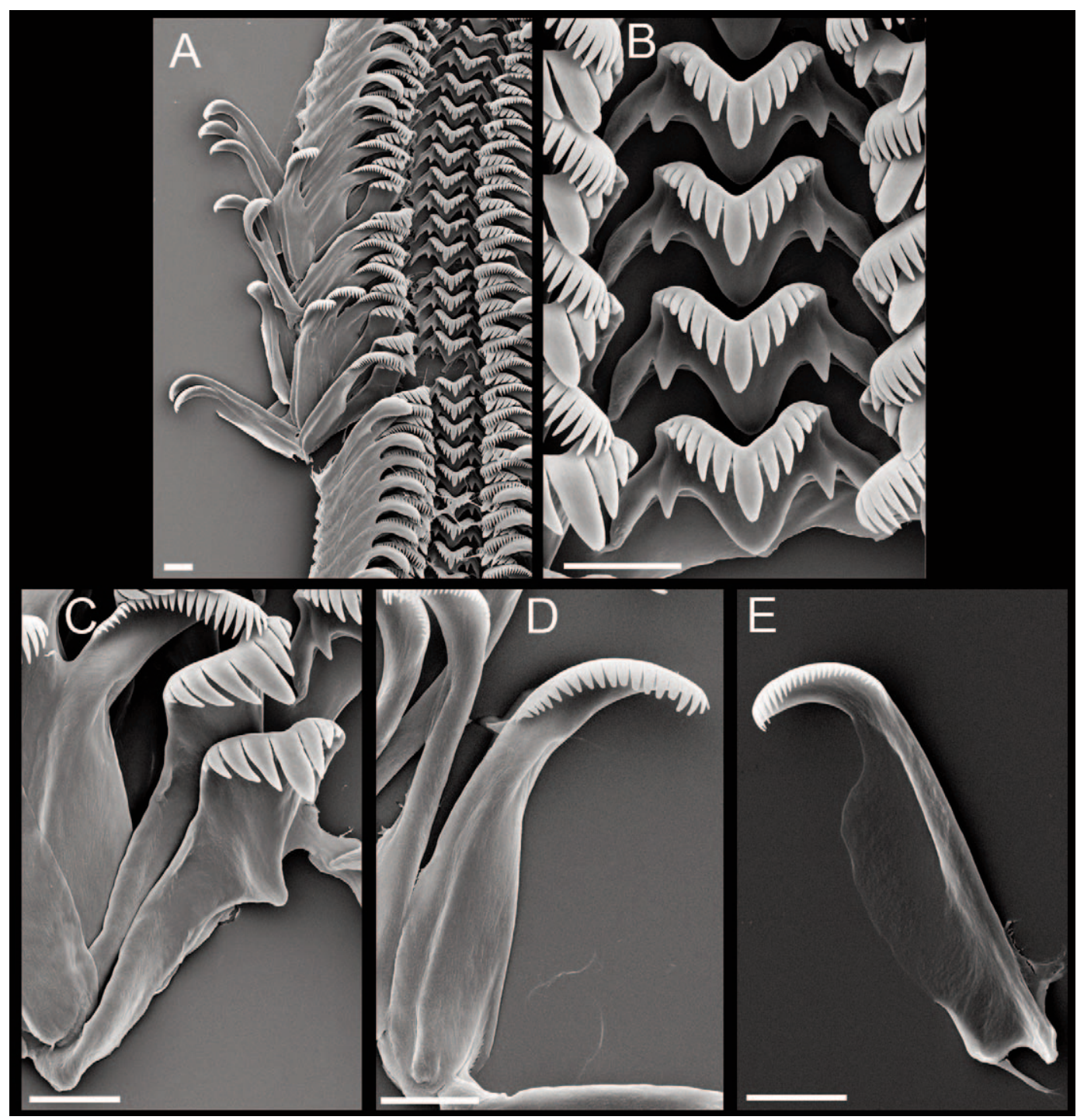

Fig. 3. Scanning electron micrographs of radula of Pyrgulopsis cybele, USNM 1157696: A, portion of radula ribbon; B, central teeth; $\mathbf{C}$, lateral and inner marginal teeth; $\mathbf{D}$, inner marginal tooth; $\mathbf{E}$, outer marginal tooth. Scale bars $=10 \mu \mathrm{m}$.

found in several other springs that were surveyed during the first author's kayak trip down the South Fork Owyhee River (from the Nevada Pipeline crossing to Three Forks) in June 2009.

REMARKs.-This nymphophiline snail is assigned to Pyrgulopsis based on the superficial position of the bursa copulatrix and bursal duct on the albumen gland, presence of a single seminal receptacle, and diffuse pattern of mantle pigmentation (per Liu and Hershler 2005:296). Pyrgulopsis cybele is distinguished from all other congeners by its unique pattern of penial ornament consisting of small glandular units on the distal edge of lobe (terminal gland), base of the filament (penial gland), and outer edge of the medial section of the penis (Dgl; see Hershler and Sada 2002 for a discussion of penial variation in this genus). It is further distinguished from its Owyhee basin congeners by its thickened inner shell lip, and mtCOI sequences (see below). The 2 populations of $P$. cybele differed in shell size (Fig. $2 \mathrm{~A}-2 \mathrm{D})$, but were closely similar in all other morphologic details. 

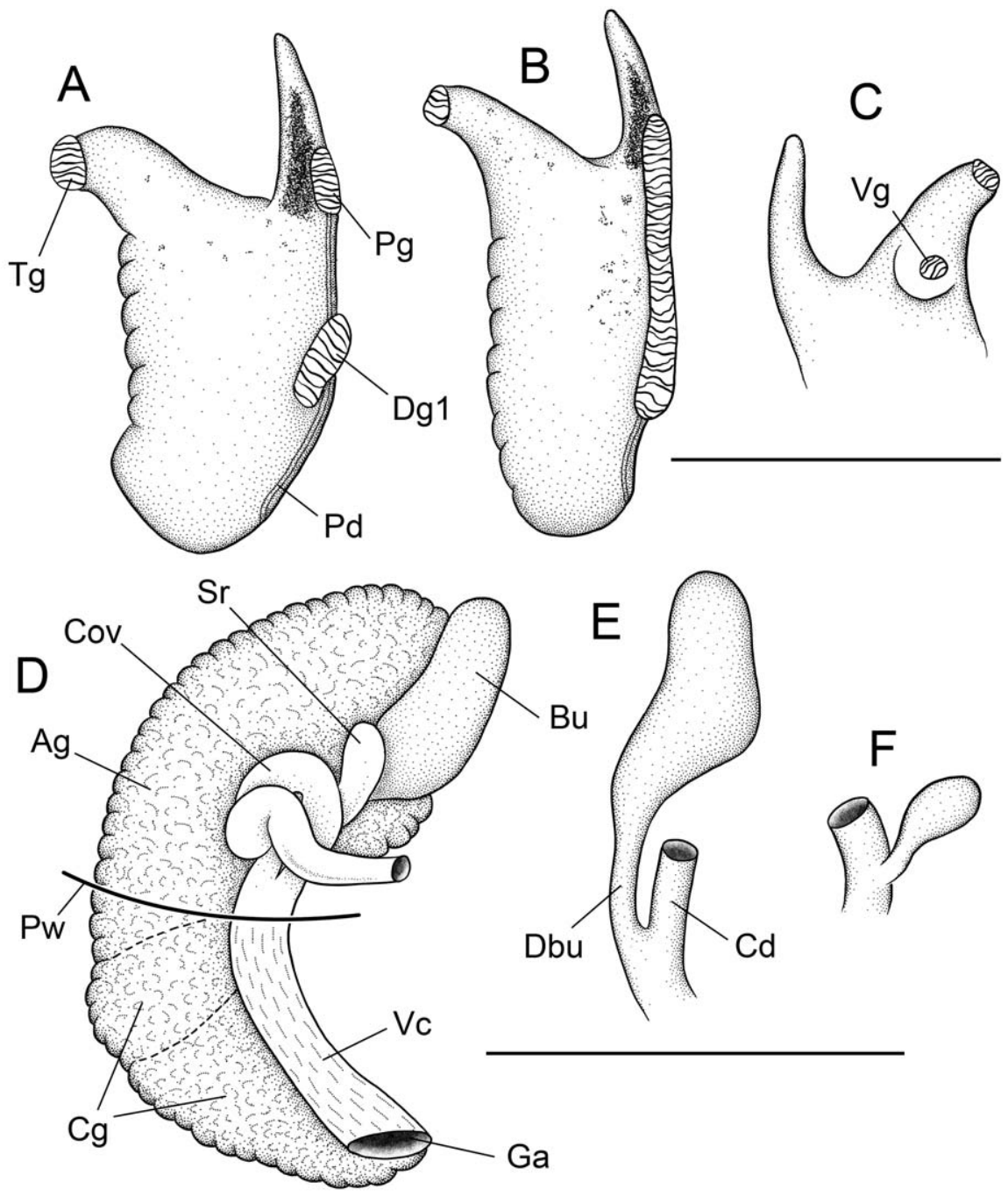

Fig. 4. Reproductive anatomy of Pyrgulopsis cybele, USNM 1157696: A, penis, dorsal surface; B, penis, ventral surface; C, penis, dorsal surface; D, female glandular oviduct and associated structures (viewed from left side); E, bursa copulatrix; F, seminal receptacle. Abbreviations: $\mathrm{Ag}$, albumen gland; $\mathrm{Bu}$, bursa copulatrix; $\mathrm{Cd}$, common duct of seminal receptacle and coiled oviduct; $\mathrm{Cg}$, capsule gland; Cov, coiled oviduct; Dbu, bursal duct; Dgl, dorsal gland along inner edge; Ga, female genital aperture; Pd, penial duct; Pg, penial gland; Pw, posterior wall of pallial cavity; Sr, seminal receptacle; Tg, terminal gland; Vc, ventral channel of capsule gland; Vg, ventral gland. Scale bars $=500 \mu \mathrm{m}$.

\section{Molecular ANALYsis}

The Bayesian analysis (Fig. 6) delineated specimens of $P$. cybele as a well-supported (100\% posterior probability) lineage nested within a (well-supported) clade composed of congeners from the Snake River, Great Basin, Colorado River, and California Pacific Coastal drainages. Pyrgulopsis intermedia and P. robusta formed a well-supported subgroup within this clade; the relationships of $P$. cybele and the other species were not well resolved. Pyrgulopsis cybele differed from other congeners included in this analysis by $3.0 \%-7.4 \%$ sequence divergence.

Five variable sites were detected among the 9 Pyrgulopsis cybele specimens that were sequenced, yielding 5 haplotypes (Table 3). These haplotypes differed from each other by $0.15 \%-0.46 \%$. Two of the haplotypes (I, II) were shared by both populations of these species. 


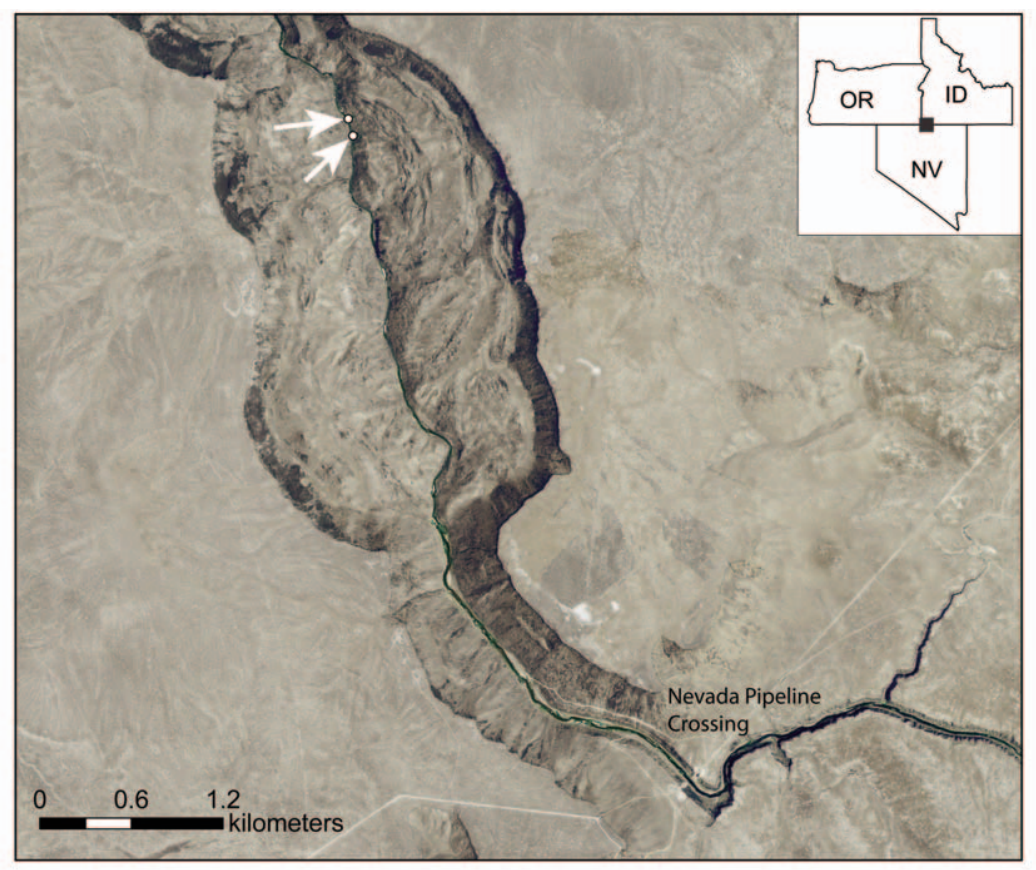

Fig. 5. Aerial (2006 National Agricultural Imagery Program) image of a portion of South Fork Owyhee River basin showing the 2 collecting localities for Pyrgulopsis cybele.

\section{DISCUSSION}

The morphologically distinctive novelty described herein does not appear to be closely related to $P$. fresti, which is endemic to springs along a lower reach of the Owyhee River (Hershler and Liu 2009), or to the 3 congeners that are distributed in the Owyhee and other drainage basins. This finding is consistent with molecular evidence that regional Pyrgulopsis faunas typically are composites of phylogenetically diverse lineages (Liu and Hershler 2005). The springs inhabited by $P$. cybele discharge through Miocene basalt, which extensively carpets the South Fork Owyhee River watershed (Coats 1987, Foord et al. 1987: plate 1). The $3.0 \% \pm 0.6 \%$ divergence of $P$. cybele relative to its most genetically similar congener $(P$. glandulosa) suggests that it evolved well subsequent to emplacement of this basalt, based on the COI molecular clock rate that has been established for Pyrgulopsis (1.62\% per million years; Hershler and Liu 2008).

Pyrgulopsis species are highly vulnerable to extirpation owing to their typically small, fragile habitats and narrow geographic ranges (Melhop and Vaughn 1994, Melhop 1996). Pyrgulopsis cybele was collected in a large wilderness study area on public land (BLM 1991). The small streams inhabited by this snail appeared to be in good condition when visited by $\mathrm{RH}$, although he did not visit their headspring sources. However, the local watershed has probably been impacted by the livestock grazing that has been occurring in this region since the late 1800s (this area is currently part of a large grazing allotment; NDA 2003). This reach of the South Fork Owyhee River watershed also may be impacted by human recreational activities (e.g., boating). The description of this locally endemic species contributes to a substantial body of evidence supporting recognition of the Owyhee Uplands as a distinct focal area of biodiversity (Vander Schaaf 1996).

\section{ACKNOWLEDGMents}

This project was supported (in part) by funds provided by the Center for Biological Diversity, Oregon Natural Desert Association (ONDA), and Western Watersheds Project. Brent Fenty (ONDA) was instrumental in helping to secure this funding. The Bureau of Land Management (Vale District) provided additional logistical support that was facilitated by Shaney Rockefeller. Chris Hansen, Dave Steele, and Dan 


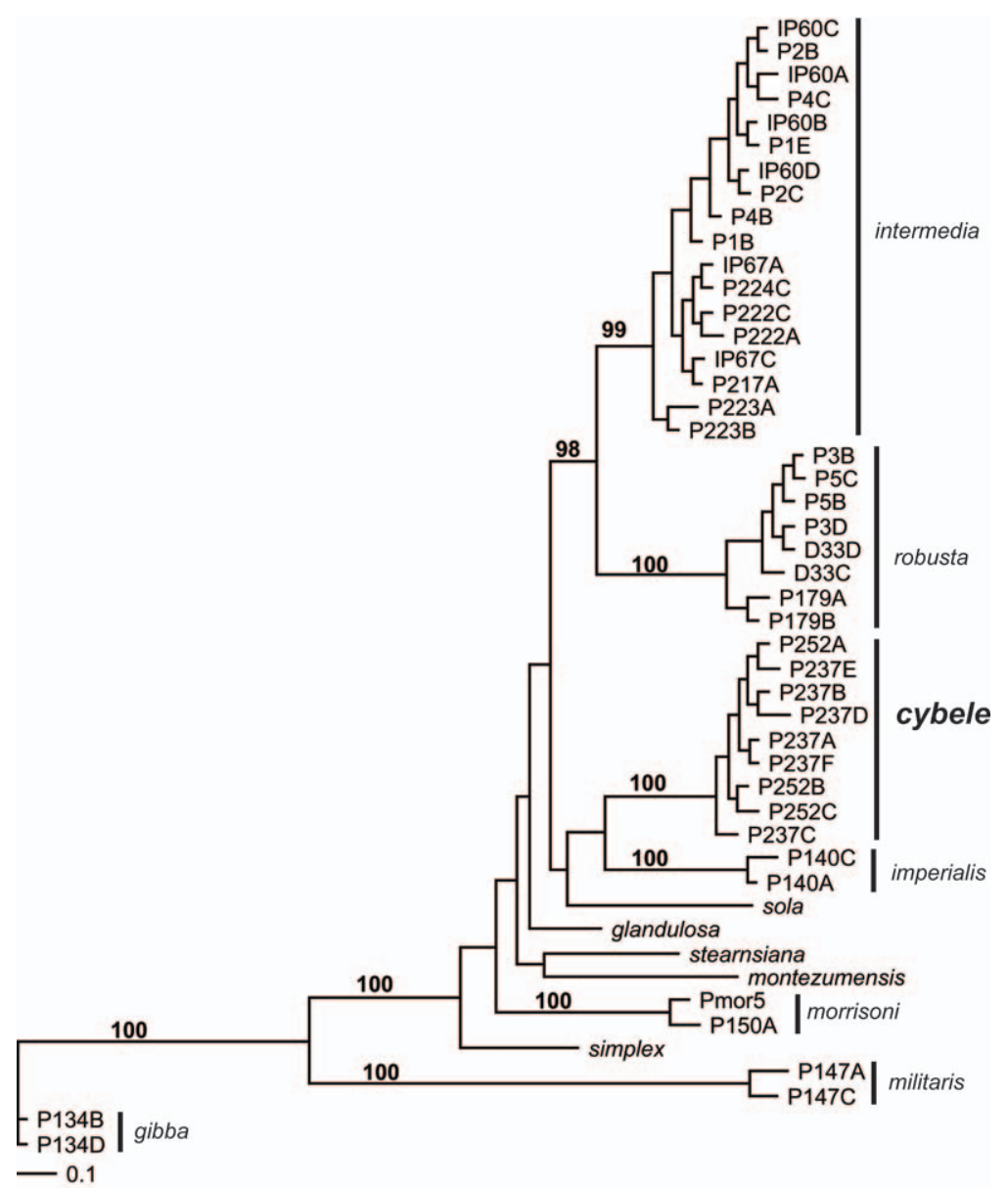

Fig. 6. Bayesian tree based on the COI (cytochrome $c$ oxidase subunit I) data set. Posterior probabilities for nodes are provided when the probabilities are $\geq 95 \%$. Terminals are labeled as in Table 1 .

TABLE 3. Variation of COI (cytochrome $c$ oxidase subunit I) within Pyrgulopsis cybele.

\begin{tabular}{lcccccc}
\hline & & \multicolumn{5}{c}{ Base pair position } \\
\cline { 3 - 7 } Specimen & Haplotype & 328 & 523 & 539 & 550 & 562 \\
\hline P252A & I & G & C & C & C & C \\
P252B & I & G & C & C & C & C \\
P252C & II & G & C & C & C & T \\
P237A & I & G & C & C & C & C \\
P237B & I & G & C & C & C & C \\
P237C & III & A & C & C & C & C \\
P237D & IV & G & C & T & T & C \\
P237E & I & G & C & C & C & C \\
P237F & V & G & T & C & C & C \\
\hline
\end{tabular}

Thomas provided a large amount of assistance in the field. We thank 2 anonymous reviewers and WNAN editor Chris Walser for their constructive comments on a draft of this manuscript.

\section{Literature Cited}

BuCKLIN, A. 1992. Use of formalin-preserved samples for molecular analysis. Newsletter of Crustacean Molecular Techniques 2:3.

[BLM] BuREau OF Land Management. 1991. Idaho wilderness study report. Volume 1. [Cited 18 August 2011]. 206 pp. Available from: http://www.blm.gov/pgdata/ etc/medialib/blm/id/plans/idaho_wilderness_study/ volume_1.Par.33337.File.dat/entiredoc.pdf

2011. Boating guide to the Bruneau, Jarbidge and Owyhee River systems. Owyhee River mapsSouth Fork (Nevada and Idaho). [Cited 18 August 2011]. Available from: http://www.blm.gov/pgdata/etc/ medialib/blm/id/rivers/owyhee_river.Par.46681.File .dat/3SFOwyRiverMaps.pdf

COATS, R.R. 1987. Geologic map of Elko County, Nevada. Nevada Bureau of Mines and Geology Bulletin 101. [Cited 18 August 2011]. Available from: http://www .nbmg.unr.edu/dox/b101.pdf

Folmer, O., M. Black, W. Hoeh, R. LutZ, and R. VRIJENHOEK. 1994. DNA primers for amplification of 
mitochondrial cytochrome $c$ oxidase subunit I from diverse metazoan invertebrates. Molecular Marine Biology and Biotechnology 3:294-299.

Foord, E.E., M.J. Luessen, D.S. HovorKa, J.L. Plesha, V.J.S. Grauch, H. Barton, and H.D. King. 1987. Mineral resources of the Owyhee Canyon and South Fork Owyhee River Wilderness Study Areas, Elko County, Nevada, and Owyhee County, Idaho. United States Geological Survey Bulletin 1719-F:1-28 + plate 1.

Frest, T.J., And E.J. Johannes. 1995. Interior Columbia Basin mollusk species of special concern. Final report (Contract \#43-00E00-4-9112) for Interior Columbia Basin Ecosystem Management Project. Deixis Consultants, Seattle, WA; [cited 16 August 2011]. 273 pp + 28 tables +17 figures. Text available from: http:// www.icbemp.gov/science/frest_1.pdf. Tables and figures available from: http://www.icbemp.gov/science/ frest 2.pdf

Hardy, M.A., T.R. Maret, and D.L. George. 2004. Reconnaissance of chemical and biological quality in the Owyhee River from the Oregon state line to the Owyhee Reservoir, Oregon, 2001-02. United States Geological Survey Water-Resources Investigations Report 03-4327. $48 \mathrm{pp}$.

Hershler, R. 1998. A systematic review of the hydrobiid snails (Gastropoda: Rissooidea) of the Great Basin, western United States. Part I. Genus Pyrgulopsis. Veliger 41:1-132.

Hershler, R., T.J. Frest, H.-P. Liu, and E.J. Johannes. 2003a. Rissooidean snails from the Pit River basin, California. Veliger 46:275-304.

Hershler, R., AND H.-P. Liv. 2004a. Taxonomic reappraisal of species assigned to the North American freshwater gastropod subgenus Natricola (Rissooidea: Hydrobiidae). Veliger 47:66-81.

2004b. A molecular phylogeny of aquatic gastropods provides a new perspective on biogeographic history of the Snake River region. Molecular Phylogenetics and Evolution 32:927-937.

.2008. Ancient vicariance and recent dispersal of springsnails (Hydrobiidae: Pyrgulopsis) in the Death Valley system, California-Nevada. Pages 91-101 in M.C. Reheis, R. Hershler, and D.M. Miller, editors, Late Cenozoic drainage history of the southwestern Great Basin and lower Colorado River region: geologic and biotic perspectives. Geological Society of America Special Paper 439.

2009. New species and records of Pyrgulopsis (Gastropoda: Hydrobiidae) from the Snake River basin, southeastern Oregon: further delineation of a highly imperiled fauna. Zootaxa 2006:1-22.

2010. Two new, possibly threatened species of Pyrgulopsis (Gastropoda: Hydrobiidae) from southwestern California. Zootaxa 2343:1-17.

Hershler, R., H.-P. Liu, T.J. Frest, and E.J. Johannes. 2007. Extensive diversification of pebblesnails (Lithoglyphidae: Fluminicola) in the upper Sacramento River basin, northwestern United States. Zoological Journal of the Linnean Society 149:371-422.

Hershler, R., H.-P. Liu, and D.L. Gustafson. 2008. A second species of Pyrgulopsis (Hydrobiidae) from the Missouri River basin, with molecular evidence supporting faunal origin through Pliocene stream capture across the northern Continental Divide. Journal of Molluscan Studies 74:403-413.
Hershler, R., H.-P. LiU, AND B.K. LANG. 2010. Transfer of Cochliopa texana to Pyrgulopsis (Hydrobiidae) and description of a third congener from the lower Pecos River basin. Journal of Molluscan Studies 76:245-256.

Hershler R., H.-P. LiU, and F.G. Thompson. 2003b. Phylogenetic relationships of North American nymphophiline gastropods based on mitochondrial DNA sequences. Zoologica Scripta 32:357-366.

HERShLER, R., AND D.W. SADA. 2002. Biogeography of Great Basin aquatic snails of the genus Pyrgulopsis. Pages 255-276 in R. Hershler, D.B. Madsen, and D.R. Currey, editors, Great Basin aquatic systems history. Smithsonian Contributions to the Earth Sciences 33.

HURT, C.R. 2004. Genetic divergence, population structure and historical demography of rare springsnails (Pyrgulopsis) in the lower Colorado River basin. Molecular Ecology 13:1173-1187.

LiU, H.-P., AND R. Hershler. 2005. Molecular systematics and radiation of western North American nymphophiline gastropods. Molecular Phylogenetics and Evolution 34:284-298.

Liv, H.-P., R. Hershler, AND K. Clift. 2003. Mitochondrial DNA sequences reveal extensive cryptic diversity within a western American springsnail. Molecular Ecology 12:2771-2782.

MELHor, P. 1996. Ecology and conservation needs of hydrobiid snails. Biodiversity Network News 9:6-7.

MeLhop, P., AND C.C. Vaughn. 1994. Threats to and sustainability of ecosystems for freshwater mollusks. Pages 68-77 in W.W. Covington and L.F. DeBano, technical coordinators, Sustainable ecological systems: implementing an ecological approach to land management. General Technical Report RM-247, USDA Forest Service, Rocky Mountain Forest and Range Experiment Station, Fort Collins, CO; [cited 10 August 2011]. Available from: http://www.fs.fed.us/rm/pubs_rm/ rm gtr247.pdf

[NDA] Nevada Department of Agriculture. 2003. Nevada public land grazing database allotment map sheet. YP Allotment. [Cited 28 November 2011]. Available from: http://agri.nv.gov/NVGRAZE/PDF/324.pdf

NyLander, J.A.A. 2004. MrModeltest v2. Program distributed by the author. Evolutionary Biology Centre, Uppsala University, Uppsala, Sweden.

RoNouist, F., AND J.P. HuELSENBECK. 2003. MRBAYES 3: Bayesian phylogenetic inference under mixed models. Bioinformatics 19:1572-1574.

[SSI] Systat Software, Inc. 2004. Systat ${ }^{\circledR}$ for Windows ${ }^{\circledR}$. Richmond, CA.

Tamura, K., D. Peterson, N. Peterson, G. Stecher, M. NEI, AND S. KUMAR. 2011. MEGA5: molecular evolutionary genetics analysis using maximum likelihood, evolutionary distance, and maximum parsimony methods. Molecular Biology and Evolution 28: 2731-2739, http://dx.doi.org/10.1093/molbev/msr121

VANDER SCHAAF, D. 1996. A report on the Owyhee Uplands Ecoregion, Oregon, Idaho, Nevada. Report prepared per a challenge cost share project between The Nature Conservancy and Vale District, BLM; [cited 19 August 2011]. 43 pp. Available from: http://onda.org/ protecting-wildlife-and-clean-water/wild-andscenic-rivers/owyhee-river/more-info/owyheprv.pdf

Received 22 August 2011 Accepted 13 January 2012 